\title{
Purification and Biochemical Properties of Glutathione $S$-Transferase from Lactuca sativa
}

\author{
Hee-Joong Park, Hyun-Young Cho and Kwang-Hoon Kong* \\ Department of Chemistry, College of Natural Sciences, Chung-Ang University, Dongjak-ku, Seoul 156-756, Korea
}

Received 18 November 2004, Accepted 22 February 2005

\begin{abstract}
A glutathione $S$-transferase (GST) from Lactuca sativa was purified to electrophoretic homogeneity approximately 403-fold with a 9.6\% activity yield by DEAE-Sephacel and glutathione (GSH)-Sepharose column chromatography. The molecular weight of the enzyme was determined to be approximately 23,000 by SDS-polyacrylamide gel electrophoresis and 48,000 by gel chromatography, indicating a homodimeric structure. The activity of the enzyme was significantly inhibited by $S$ hexylGSH and $S$-(2,4-dinitrophenyl) glutathione. The enzyme displayed activity towards 1-chloro-2,4-dinitrobenzene, a general GST substrate and high activities towards ethacrynic acid. It also exhibited glutathione peroxidase activity toward cumene hydroperoxide.
\end{abstract}

Keywords: Enzymatic characterization, Glutathione, $S$-tranferase, Homodimer, Lactuca sativa, Lettuce, Purification, Substrate specificity

\section{Introduction}

Glutathione $S$-transferase (GST, EC 2.5.1.18) is a family of multifunctional proteins, catalyzing the formation of conjugates between reduced glutathione (GSH) and a wide variety of electrophilic compounds including alkyl- and aryl halides, epoxides, esters and alkenes (Mannervik et al., 1988). Certain GSTs can also detoxify lipid and DNA hydroperoxide by their intrinsic peroxidase activity. Others catalyze the isomerization of certain steroids and play an important role in the intracellular transport of numerous hydrophobic

\footnotetext{
Abbreviations: CDNB, 1-chloro-2,4-dinitrobenzene; GSH, glutathione; GST, glutathione $S$-transferase; SDS-PAGE, sodium dodecyl sulfate-polyacrylamide gel electrophoresis.
}

*To whom correspondence should be addressed.

Tel: 82-2-820-5205; Fax: 82-2-825-4736

E-mail: khkong@cau.ac.kr nonsubstrate ligands such as bile acids, billirubin and a number of drugs.

GSTs are distributed in a wide range of organisms from mammal to E. coli (Fahey et al., 1991). Mammalian GSTs can be grouped into at least four distinct classes, alpha, mu, pi and theta according to their structures and catalytic properties (Mannervik et al., 1992). The enzymes have been extensively purified from mammals such as human, mouse, cattle and rat, and their structure, function and physiological significance have been studied in detail (Beckett et al., 1993; Beckett et al., 1994; Armstrong, 1997). Plant GST has been concerned in the agricultural chemistry and biochemistry because it is one of the major factors involved in the resistance of a variety of herbicides and insecticides (Lamoureux et al., 1980; Leurs et al., 1989). The first GST reported to participate in herbicide metabolism was isolated from maize and characterized in some detail (Mozer et al., 1983; Moore et al., 1986; Grove et al., 1988; Izuka et al., 1989; Irzyk et al., 1993, 1995). GSTs play roles in plants, having been implicated in herbicide resistance, being inducible by pathogens and/or dehydration, showing direct binding of auxins and catalyzing the formation of anthocyanins (Sheehan et al., 2001). Plant GSTs have also been studied from wheat (Riechers et al., 1997), tobacco (Droog et al., 1995), carnation (Itzhaki et al., 1993) and broccoli (Lopez et al., 1994). Despite these efforts, the data on plant GSTs are largely lacking, and little is known about the biological function, structures and regulations of plant GSTs. In this study, a GST from the leaves of lettuce (Lactuca sativa) was purified, characterized the enzymatic properties and compared its properties with those of enzymes from other sources. This study is the first report on glutathione $S$ transferase in lettuce (Lactuca sativa), and it will be of great value in designing new herbicides having a high selectivity.

\section{Materials and Methods}

Materials The leaves of lattuce (Lactuca sativa L.) used in this study was purchased from Huksuk market. Glutathione (GSH), 1- 
chloro-2,4-dinitrobenzene (CDNB), 1,2-dichloro-4-nitrobenzene (DCNB), ethacrynic acid (ETA), 1,2-epoxy-3-(p-nitrophenoxy) propane (EPNP), DEAE-Sephacel and glutathione-Sepharose were obtained from Sigma (St. Louis, USA). S-(2,4-dinitrophenyl) glutathione was synthesized by the method of Schramm et al. Benastatin A was gifted by Prof. T. Aoyagi (Aoyagi et al., 1992). All other reagents used were of the highest grade commercially available.

Preparation of enzyme The leaves of lettuce were homogenized 5 times with $100 \mathrm{mM}$ potassium phosphate buffer $(\mathrm{pH} 7.0$ ) containing $5 \mathrm{mM}$ polyethylene glycol in a waring blender for $1 \mathrm{~min}$. The mixture was centrifuged at $20,000 \times g$ for $30 \mathrm{~min}$, yielding the crude extracts. This solution was dialyzed 3 times with changes every $8 \mathrm{hrs}$ against $20 \mathrm{mM}$ potassium phosphate buffer $(\mathrm{pH}$ 7.0) containing $1 \mathrm{mM}$ EDTA and $1 \mathrm{mM}$ 2-mercaptoethanol (buffer A). The dialyzed solution was applied to a DEAE-Sephacel column $(25 \times 250 \mathrm{~mm})$ equilibrated with buffer A. After washing the column with buffer A, bound proteins were eluted with a linear gradient of $0-500 \mathrm{mM} \mathrm{NaCl}$ in buffer $\mathrm{A}$ at $0.4 \mathrm{ml} / \mathrm{min}$. The active fractions were pooled, dialyzed against buffer $\mathrm{A}$ and loaded onto a 15-ml column of glutathione-Sepharose equilibrated with buffer A. The column was exhaustively washed with the same buffer. The enzyme was eluted with $50 \mathrm{mM}$ Tris- $\mathrm{HCl}$ buffer $(\mathrm{pH}$ 9.6) containing $10 \mathrm{mM}$ GSH and dialyzed against buffer A. This dialyzed purified enzyme was used for next experiment. Unless otherwise indicated, all purification procedures were performed either at $4^{\circ} \mathrm{C}$ or on ice. The enzymes were stored at $-70^{\circ} \mathrm{C}$ until use.

Enzyme activity and kinetic studies The specific activities were determined by measuring the initial rates of the enzyme-catalysed conjugation of GSH with CDNB (1-chloro-2,4-nitrobenzene), DCNB (1,2-dichloro-4-nitrobenzene), EPNP (1,2-epoxy-3-( $p$ nitrophenoxy) propane and ETA (ethacrynic acid) as described by Habig and Jakoby (Habig et al., 1981). GSH-dependent peroxidase activity was assayed as described by Mannervik (Mannervik, 1985). Kinetic studies with GSH and CDNB were performed at $30^{\circ} \mathrm{C}$ as described by Ivanetich and Goold (Ivanetich et al., 1989). The enzyme was preincubated for $2 \mathrm{~min}$ at $30^{\circ} \mathrm{C}$ with a desired concentration of CDNB. Nonenzymatic reaction rates were subtracted from the reaction rate in the presence of enzyme. The concentrations of enzyme used for initial rate studies was varied in the range of $1-50 \mu \mathrm{g} / \mathrm{ml}$. The concentrations of GSH and CDNB were varied in the range of $0.075-1 \mathrm{mM}$ and $0.1-1 \mathrm{mM}$, respectively. Kinetic parameters were obtained from hyperbolic saturation curves by least squares fit of the initial velocity data to the equation of rapid equilibrium random sequential $\mathrm{Bi} \mathrm{Bi}$ mechanism. Protein concentration of the enzyme was determined using a protein assay reagent (Bio-Rad Lab., Richmond, USA).

Inhibition studies The inhibitory effects on the activity of the enzyme were measured by preincubating the enzyme with $1 \mathrm{mM}$ GSH and the inhibitor for $2 \mathrm{~min}$ and initiating the reaction by addition of $1 \mathrm{mM} \mathrm{CDNB}$ at $30^{\circ} \mathrm{C}$. The concentration of inhibitor giving 50\% inhibition $\left(\mathrm{I}_{50}\right)$ was determined from plot of residual activity against inhibitor concentration.

Heat inactivation assays The enzyme was incubated at each temperature for $10 \mathrm{~min}$ at a protein concentration of $50 \mu \mathrm{g} / \mathrm{ml}$ in 20 $\mathrm{mM}$ potassium phosphate buffer $(\mathrm{pH}$ 7.0) containing $10 \mathrm{mM}$ DTT and $10 \mathrm{mM}$ EDTA, to prevent the oxidative inactivation. The remaining activity was assayed in $100 \mathrm{mM}$ potassium phosphate buffer (pH 6.5) with $1 \mathrm{mM} \mathrm{GSH}$ and $1 \mathrm{mM} \mathrm{CDNB}$ at $30^{\circ} \mathrm{C}$.

Molecular size determination The molecular weight was also determined using fast protein liquid chromatography (FPLC) on a Superdex 200 HR column (Pharmacia Biotech, Sweden) according to the method described previously (Hong et al., 1999). Molecular size standards used were blue dextran, yeast alcohol dehydrogenase, bovine serum albumin, trypsin inhibitor and cytochrome c (Sigma).

Electrophoresis Denaturing SDS-PAGE was carried out by the method of Laemmli (1970) in 12.5\% gels. The molecular-mass makers were SDS molecular weight standard markers (Bio-Rad) that contains phosphorylase B $(97.4 \mathrm{kDa})$, bovine serum albumin $(66.2 \mathrm{kDa})$, ovalbumin $(45.0 \mathrm{kDa})$, carbonic anhydrase $(31.0 \mathrm{kDa})$, soybean trypsin inhibitor $(21.5 \mathrm{kDa})$ and lysozyme $(14.4 \mathrm{kDa})$. Coomassie Blue R-250 was used for staining (Kim et al., 2002).

\section{Results}

Purification, homogeneity and molecular weight The results of the purification of the GST present in Lactuca sativa was summarized in Table 1. GSH-conjugating activity toward CDNB in the crude extract was very low. Following chromatography on DEAE-Sephacel of the crude extract, a single peak of GST activity was eluted between 100 and 150 $\mathrm{mM} \mathrm{NaCl}$ with an increase in specific activity of approximately 7 times. After passage through the GSHSepharose column, the specific activity further increased to approximately 403 times, with an overall recovery of around $9.6 \%$ of the initial activity.

The purified enzyme gave a single band on electrophoresis in the presence of SDS. Comparison of relative mobility of the

Table 1. Purification of glutathione $S$-transferase from Lactuca sativa

\begin{tabular}{cccccc}
\hline Step & $\begin{array}{c}\text { Total activity } \\
(\mu \mathrm{mol} / \mathrm{min})\end{array}$ & $\begin{array}{c}\text { Total protein } \\
(\mathrm{mg})\end{array}$ & $\begin{array}{c}\text { Specific activity } \\
(\mu \mathrm{mol} / \mathrm{min} \text { per } \mathrm{mg})\end{array}$ & $\begin{array}{c}\text { Yield } \\
(\%)\end{array}$ & $\begin{array}{c}\text { Purification } \\
(\text { fold })\end{array}$ \\
\hline Crude extract & 8.41 & 621 & 0.01 & 100 & 1 \\
DEAE-Sephacel & 5.43 & 77.57 & 0.07 & 65 & 7 \\
GSH-Sepharose & 0.81 & 0.201 & 4.03 & 9.6 & 403 \\
\hline
\end{tabular}

One unit of enzyme produces $1 \mu \mathrm{mol}$ of $S$-(2,4-dinitrophenyl)glutathione per min at $30^{\circ} \mathrm{C}$. 


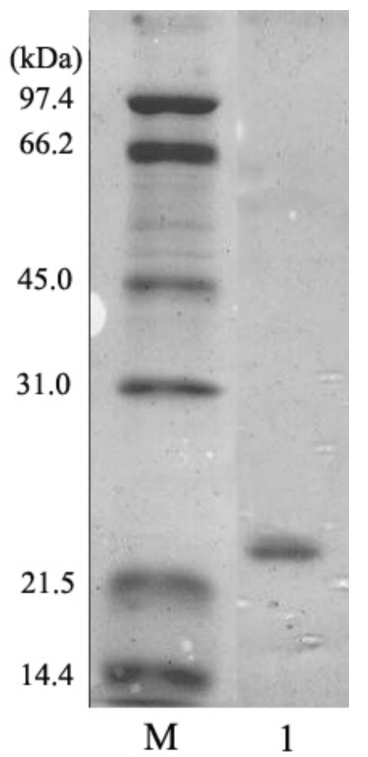

Fig. 1. Electrophoresis of the Lactuca sativa GST under denaturing conditions. Denaturing SDS-PAGE was carried out using the method of Laemmli (1970) in $12.5 \%$ gel. Coomassie blue R-250 was used for staining. Lane M, molecular mass marker (Bio-Rad); lane 1, GSH-Sepharose column chromatography.

enzyme with a standard protein indicated that a molecular weight of the Lactuca sativa GST was approximately 23,000 by SDS-PAGE (Fig. 1).

Substrate specificity Substrate specificity of the Lactuca sativa GST toward several compounds was shown in Table 2. The enzyme displayed GSH-conjugating activity towards 1chloro-2,4-dinitrobenzene (CDNB), 1,2-epoxy-3-(p-nitrophenoxy) propane(EPNP) and ethacrynic acid (ETA). On the other hand, there was no detectable activity toward 1,2-dichloro-4nitrobenzene. The Lactuca sativa GST also exhibited glutathione peroxidase activity toward cumene hydroperoxide with a specific activity of $0.32 \mu \mathrm{mol} \mathrm{min} \mathrm{m}^{-1}$ per $\mathrm{mg}$ of protein.

Inhibition studies The inhibition parameters $\left(\mathrm{I}_{50}\right)$ of various inhibitors, $S$-hexylGSH, $S$-methylGSH, benastatin A, ethacrynic acid and $S$-(2,4-dinitrophenyl)glutathione for the GSH-CDNB conjugating activity were determined under the standard assay conditions (Table 3 ). The $\mathrm{I}_{50}$ value of $S$-hexylGSH and $S$ methylGSH, a derivative of GSH, for the enzyme was approximately $15 \mu \mathrm{M}$. The $\mathrm{I}_{50}$ of benastatin A, an electrophilic substrate-like compound (Aoyagi et al., 1992) and S-(2,4dinitrophenyl)glutathione, a conjugation product of GSH with $\mathrm{CDNB}$, for the enzyme were $0.41 \mu \mathrm{M}$ and $3.4 \mu \mathrm{M}$, respectively.

Thermostability The thermostability of the enzyme was also investigated by incubation of the enzyme at various temperatures for $10 \mathrm{~min}$. The midpoint of the temperaturestability curve was approximately $53^{\circ} \mathrm{C}$ for the enzyme (Fig. 2). The enzyme was stable to such incubation at temperatures
Table 2. Substrate specificity of the Lactuca sativa glutathione $S$ transferase

\begin{tabular}{lc}
\hline \multicolumn{1}{c}{ Substrates } & $\begin{array}{c}\text { Specific Activity } \\
(\mu \mathrm{mol} / \mathrm{min} \text { per } \mathrm{mg})\end{array}$ \\
\hline 1-Chloro-2,4-dinitrobenzene & $4.03 \pm 0.23$ \\
1,2-Dichloro-4-nitrobenzene & $\mathrm{ND}^{\mathrm{a}}$ \\
Ethacrynic acid & $6.21 \pm 0.10$ \\
1,2-Epoxy-3-(p-nitrophenoxy)propane & $8.78 \pm 0.03$ \\
Cumene hydroperoxide & $1.32 \pm 0.01$ \\
\hline
\end{tabular}

Values are Means \pm S.D., generally based on $n \geq 5$.

$\mathrm{ND}^{\mathrm{a}}$, No detected activity.

Table 3. Inhibition effect of $S$-hexyl-GSH, $S$-methyl-GSH, benastatin A, $S$-(2,4-dinitrophenyl)glutathione and ethacrynic acid on GSH-CDNB conjugation of the Lactuca sativa glutathione $S$ transferase

\begin{tabular}{lc}
\hline \multicolumn{1}{c}{ Inhibitors } & $\mathrm{I}_{50}(\mu \mathrm{M})$ \\
\hline$S$-hexyl-GSH & $15.20 \pm 0.10$ \\
$S$-methyl-GSH & $12.30 \pm 0.07$ \\
Benastatin A & $0.41 \pm 0.10$ \\
$S$-(2,4-dinitrophenyl)glutathione & $3.40 \pm 0.03$ \\
Ethacrynic acid & $0.28 \pm 0.04$ \\
\hline
\end{tabular}

Values are Means \pm S.D., generally based on $n \geq 5$.

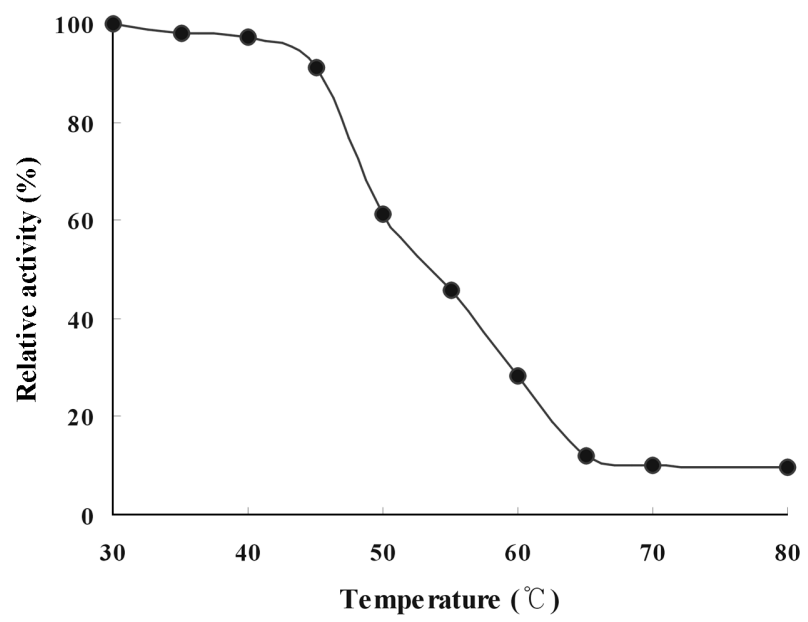

Fig. 2. Thermostability on the Lactuca Sativa GST. The enzyme was heated at each temperature for $10 \mathrm{mim}$.

up to $45^{\circ} \mathrm{C}$. Above $50^{\circ} \mathrm{C}$, its activities declined rapidly as the temperature increased, but the enzyme was not completely inactivated even at $80^{\circ} \mathrm{C}$.

\section{Discussion}

Glutathione $S$-transferase from Lactuca sativa was purified to apparent homogeneity with the use of standard techniques, i.e. 
anion exchange chromatography and affinity chromatography. The molecular weight of the purified Lactuca sativa GST was estimated to be 23,000 by SDS-polyacrylamide gel electrophoresis. On the other hand, runs of the purified enzyme in size-exclusion chromatography together with molecular weight markers indicated that the activity eluted at a point corresponding to a protein of approximately 48,000. It is then concluded that the active form of the Lactuca sativa GST is a homodimer of two equal polypeptides of 23,000. The Lactuca sativa GST seemed to be similar to those of mammalian, plant and microorganism enzymes, all of which are dimers with a molecular weight of 40,000 to 60,000 (Mozer et al., 1983; Kong et al., 1991; Nishida et al., 1994). However, it was different from the enzyme of Tetrahymena thermophila that was a monomer with a molecular weight of 33,000 to 35,000 (Overbaugh et al., 1988).

One prominent feature of GST is the presence of a number of isoenzymes within a given species (Mannervik et al., 1988). According to the sequence comparisons, substrate specificities, sensitivities to inhibitors, $N$-terminal amino acid sequence and exon-intron compositions , the majority of GST purified from plant (Mozer et al., 1983) were grouped into phi, zeta, tau and theta (Sheehan et al., 2001). Only one form of GST was also reported from Xanthomonas campestris (Di Ilio et al., 1993) and E. coli K-12 (Nishida et al., 1994). The Lactuca sativa GST was not significantly active with CDNB, the substrate most often used in the assay of GSTs (Table 2). The activity of the enzyme toward CDNB was significantly lower than the enzymes from mouse, corn and F. oxysporum (Lee et al., 1981; Mozer et al., 1983; Ando et al., 1988). On the other hand, it was similar to those of the enzymes from bacteria (Izuka et al., 1989; Nishida et al., 1994).

The Lactuca sativa GST was retained on GSH-affinity column and its apparent $K_{\mathrm{m}}$ value for GSH was calculated at $0.42 \mathrm{mM}$, which was in general agreement with published $K_{\mathrm{m}}{ }^{\mathrm{GSH}}$ values of other GSTs (Aceto et al., 1993; Bartling et al., 1993; Hahn et al., 1994; Kong et al., 1997). The $\mathrm{I}_{50}$ values of the enzyme for $S$-hexylGSH and $S$-(2,4-dinitrophenyl) glutathione also were within the range reported for other GSTs (Table 3). These results suggest that the GSH-binding site of the Lactuca sativa GST may be similar to those of other GSTs. Three-dimensional structure of GST from plant (Arabidopsis thaliana) showed an overall similarity to other GSTs particularly in the GSH-binding domain (Reinemer et al., 1996). In contrast, the $K_{\mathrm{m}}$ value of the Lactuca sativa GST for CDNB was $1.42 \mathrm{mM}$, which was 1 order of magnitude lower than $\mathrm{Km}$ values reported for the enzymes from Arabidopsis thaliana (Bartling et al., 1993) and potato (Hahn et al., 1994). Its $I_{50}$ value for benastatin A, an electrophilic substrate-like compound (Table 3) also was significantly lower than the $I_{50}$ value reported for human pi-class GST (Kong et al., 1997). These data indicate a higher affinity of the Lactuca sativa GST for electrophilic substrate.

The Lactuca sativa GST also was not significantly active with 1,2-dichloro-4-nitrobenzene, a marker substrate for the mu-class enzymes (Table 2). However, the enzyme had a significantly high specific activities towards 1,2-epoxy-3-( $p$ nitrophenoxy)propane, a marker substrate for the theta-class of GSTs. Theta-class transferase which were active towards these substrates had been isolated from human liver (Meyer $e t$ al., 1991) and broccoli (Lopez et al., 1994). The purified Lactuca sativa GST showed selenium-independent glutathione peroxidase activity when cumene hydroperoxide was used as a substrate. The theta-class GSTs purified from Arabidopsis thaliana and mouse liver exhibited selenium-independent glutathione peroxidase activity (Bartling et al., 1993; Hiratsuka et al., 1995). On the other hand, E. coli B GST showed neither selenium-dependent nor independent glutathione peroxidase activity, indicating that the properties of catalytic sites between eukaryote and prokaryote enzymes may be different (Izuka et al., 1989). The molecular cloning of the GST gene of Lactuca sativa is now in progress in order to elucidate the difference in the molecular structure between the Lactuca sativa GST and enzymes of other sources.

Acknowledgment This research was supported by the Chung-Ang University Research Grants in 2004.

\section{References}

Aceto, A., Dragani, B., Bucciarelli, T., Sacchetta, P., Martini, F., Angelucci, S., Amicarelli, F., Miranda, M. and Di Ilio, C. (1993) Purification and characterization of the major glutathione transferase from adult toad (Bufo bufo) liver. Biochem. J. 289, 417-422.

Ando, K., Honma, M., Chiba, S., Tahara, S. and Mizutani, J. (1988) Glutathione transferase from Mucor javanicus. Agric. Biol. Chem. 52, 135-139.

Aoyagi, T., Aoyama, T., Kojima, F., Matsuda, N., Maruyama, M., Hamada, M. and Takeuchi, T. (1992) Benastatins A and B, new inhibitors of glutathions $S$-transferase, produced by Streptomyces sp. MI384-DF12. I. Taxonomy, production, isolation, physico-chemical properties and biological activities. J. Antibiot. 45, 1385-1390.

Armstrong, R. N. (1997) Structure, catalytic mechanism, and evolution of the glutathione transferases. Chem. Res. Toxicol. 10, 2-18.

Bartling, D., Radzio, R., Steiner, U. and Weiler, E. W. (1993) A glutathione $S$-transferase with glutathione-peroxidase activity from Arabidopsis thaliana. Eur. J. Biochem. 216, 579-586.

Beckett, G. J. and Hayes, J. D. (1993) Glutathione $S$-transferases: biomedical applications. Adv. Chim. Chem. 30, 281-380.

Di Ilio, C., Aceto, A., Allocati, N., Piccolomini, R., Bucciarelli, T., Dragani, B., Faraone, A., Sacchetta, P., Petruzzelli, R. and Federici, G. (1993) Characterization of glutathione transferase from Xanthomonas campestris. Arch. Biochem. Biophys. 305, 110-114.

Dirr, H., Reinemer, P. and Huber, R. (1994) X-ray crystal structures of cytosolic glutathione $S$-transferases. Implications for protein architecture, substrate recognition and catalytic functions. Eur. J. Biochem. 220, 645-661.

Dominey, R. J., Nimmo, I. A., Cronshaw, A. D. and Hayes, J. D. 
(1991) The major glutathione $S$-transferase in Salmonid fish livers is homologous to the mammalian pi-class GST. Comp. Biochem. Physiol. 100, 93-98.

Droog, F., Spek, A., van der Kooy, A., de Ruyter, A., Hoge, H., Libbenga, K., Hooykaas, P. and van der Zaal, B. (1995) Promoter analysis of the auxin-regulated tobacco glutathione $S$ transferase genes Nt103-1 and Nt103-35. Plant. Mol. Biol. 29, 413-429.

Fahey, R. C. and Sundquist, A. R. (1991) Evolution of glutathione metabolism. Adv. Enzymol. Rel. Areas Mol. Biol. 64, 1-53.

Grove, G., Zarlengo, R. P., Timmerman, K. P., Li, N. Q., Tam, M. F. and Tu, C. P. (1988) Characterization and heterospecific expression of cDNA clones of genes in the maize GSH $S$ transferase multigene family. Nucleic. Acids. Res. 16, 425-438.

Habig, W. H. and Jakoby, W. B. (1981) Assays for differentiation of glutathione $S$-transferase. Methods Enzymol. 77, 398-405.

Hahn, K. and Strittmatter, G. (1994) Pathogen-defence gene prp11 from potato encodes an auxin-responsive glutathione $S$ transferase. Eur. J. Biochem. 226, 619-626.

Hiratsuka, A., Kanazawa, M., Nishiyama, T., Okuda, H., Ogura, K. and Watabe, T. (1995) A subfamily 2 homo-dimeric glutathione $S$-transferase mYrs-mYrs of class theta in mouse liver cytosol. Biochem. Biophys. Res. Commun. 212, 743-750.

Hong, S.-H., Park, H.-J. and Kong, K.-H. (1999) Purification and biochemical properties of glutathione $S$-transferase from Oryza sativa. Comp. Biochem. Physiol. 122, 21-27.

Irzyk, G. P. and Fuerst, E. P. (1993) Purification and characterization of a glutathione $S$-transferase from benoxacortreated maize (Zea mays). Plant. Physiol. 102, 803-810.

Irzyk, G., Potter, S., Ward, E. and Fuerst, E. P. (1995) A cDNA clone encoding the 27-kilodalton subunits of glutathione $S$ transferase IV from Zea mays. Plant. Physiol. 107, 311-312.

Itzhaki, H. and Woodson, W. R. (1993) Characterization of an ethylene-responsive glutathione $S$-transferase gene cluster in carnation. Plant. Mol. Biol. 22, 43-58.

Ivanetich, K. M. and Goold, R. D. (1989) A rapid equilibrium random sequential bi-bi mechanism for human placental glutathione $S$-transferase. Biochim. Biophys. Acta 998, 7-13.

Izuka, M., Inoue, Y., Murata, K. and Kimura, A. (1989) Purification and some properties of glutathione $S$-transferase from Escherichia coli B. J. Bacteriol. 171, 6039-6042.

Jepson, I., Lay, V. J., Holt, D. C., Bright, S. W. and Greenland, A. J. (1994) Cloning and characterization of maize herbicide safener-induced cDNAs encoding subunits of glutathione $S$ transferase isoforms I, II and IV. Plant. Mol. Biol. 26, 18551866.

Kim, S.-K., Park, P.-J., Kim, J.-B. and Shahidi F. (2002) Purification and Characterization of a Collagenolytic Protease from the Filefish, Novoden modestrus. J. Biochem. Mol. Biol. 35, 165-171.

Kong, K.-H., Inoue, H. and Takahashi, K. (1991) Non-essentiality of cysteine and histidine residues for the activity of human class pi glutathione $S$-transferase. Biochem. Biophys. Res. Commun. 181, 748-755.

Kong, K.-H., Park, H.-J., Inoue, H. and Takahashi, K. (1997) Functional analysis of the evolutionary conserved arginine 182 residue in human glutathione $S$-transferase P1-1. Biochem. Mol. Biol. Int. 43, 251-262.

Laemmli, U. K. (1970) Cleavage of structural proteins during the assembly of the head of bacteriophage T4. Nature 227, 680-
685.

Lamoureux, G. L. and Rusness, D. G. (1980) Pentachloronitrobenzene etabolism in peanut. 1. Mass spectral characterization of seven glutathione-related conjugates produced in vivo or in vitro. $J$. Agric. Food. Chem. 28, 1057-1070.

Lee, C.-Y., Johnson, L., Cox, R. H., McKinney, J. D. and Lee, S.M. (1981) Mouse liver glutathione $S$-transferase: biochemical and immunological characterization. J. Biol. Chem. 256, 81108116.

Leurs, R., Donnell, D., Timmerman, H. and Bast, A. (1989) Interaction of nefopam and orphenadrine with the cytochrome P-450 and the glutathione system in rat liver. J. Pharm. Pharmacol. 41, 388-393.

Lopez, M. F., Patton, W. F., Sawlivich, W. B., ErdjumentBromage, H., Barry, P., Gmyrek, K., Hines, T., Tempst, P. and Skea, W. M. (1994) A glutathione $S$-transferase (GST) isozyme from broccoli with significant sequence homology to the mammalian theta-class of GSTs. Biochem. Biophys. Acta. 1205, 29-38.

Mannervik, B. (1985) Glutathione peroxidase. Methods Enzymal. 113, 490-495.

Mannervik, B. and Danielson, U. H. (1988) Glutathione transferases-structure and catalytic activity. CRC Crit. Rev. Biochem. 23, 283-337.

Mannervik, B., Awasthi, Y. C., Board, P. G., Hayes, J. D., Ilio, C., Ketterer, B., Listowsky, I., Morgenstern, R., Muramatsu, M., Pearson, W. R., Pickett, C. B., Sato, K., Widersten, M. and Wolf, C. R. (1992) Nomenclature for human glutathione transferases. Biochem. J. 282, 305-308.

Meyer, D. J., Coles, B., Pemble, S. E., Gilmore, K. S., Fraser, G. M. and Ketterer, B. (1991) Theta, a new class of glutathione transferases purified from rat and man. Biochem. J. 274, 409414.

Meyer, D. J., Gilmore, K. S., Coles, B., Dalton, K., Hulbert, P. B. and Ketterer, B. (1991) Structural distinction of rat GSH transferase subunit 10. Biochem. J. 274, 619-624.

Moore, R. E., Davies, M. S., O'Connell, K. M., Harding, E. I., Wiegand, R. C. and Tiemeier, D. C. (1986) Cloning and expression of a cDNA encoding a maize glutathione $S$ transferase in E. coli. Nucleic. Acids. Res. 14, 7227-7235.

Mozer, T. J., Tiemeier, D. C. and Jaworski, E. G. (1983) Purification and characterization of corn glutathione $S$ transferase. Biochemistry 22, 1068-1072.

Nishida, M., Kong, K.-H., Inoue, H. and Takahashi, K. (1994) Molecular cloning and site-directed mutagenesis of glutathione S-transferase from Escherichia coli. J. Biol. Chem. 269, 3253632541.

Overbaugh, J. M., Lau, P. E., Marino, V. A. and Fall, R. (1988) Purification and preliminary characterization of amonomeric glutathione $S$-transferase from Tetrahymena thermophila. Arch. Biochem. Biophys. 261, 227-234.

Pemble, S. E. and Taylor, J. B. (1992) An evolutionary perspective on glutathione transferase inforred from class-Theta glutathione transferase cDNA sequences. Biochem. J. 287, 957-963.

Reinemer, P., Prade, L., Hof, P., Neuefeind, T., Huber, R., Zettl, R., Palme, K., Schell, J., Koelln, I., Bartunik, H. D. and Bieseler, B. (1996) Three-dimensional structure of glutathione $S$-transferase from Arabidopsis thaliana at $2.2 \AA$ resolution: Structural characterization of herbicide-conjugating plant glutathione $S$-transferase and a novel active site architecture. $J$. 
Mol. Biol. 255, 289-309.

Riechers, D. E., Irzyk, G. P., Jones, S. S. and Fuerst, E. P. (1997) Partial characterization of glutathione $S$-transferase from wheat (Triticum spp.) and purification of a safener-induced glutathione $S$-transferase from Triticum tauschii. Plant. Physiol. 114, 1461-1470.

Schramm, H., Robertson, L. W. and Oesch, F. (1985) Differential regulation of hepatic glutathione transferase and glutathione peroxidase activities in the rat. Biochem. Pharmacol. 34, 37353739.

Sheehan, D., Meade, G., Foley, V. M. and Dowd, C. A. (2001) Structure, function and evolution of glutathione transferases: implication for classification of non-mammalian members of an ancient enzyme superfamily. Biochem. J. 360, 1-16. 